\title{
INTEREST RATES CLOSE TO ZERO, POST-CRISIS RESTRUCTURING AND NATURAL INTEREST RATE
}

\author{
Piotr Ciżkowicz, Andrzej Rzońca*
}

\begin{abstract}
:
Central banks do not seem to account for the impact of interest rates close to zero on the natural interest rate after the bursting of the asset bubble that triggered the financial crisis in 2008. We claim that this omission may have harmful consequences. Should interest rates close to zero persistently decrease natural interest rates that would mean a fall in TFP growth and more limited central bank's capacity to influence aggregated demand and price dynamics. We explain that interest rates close to zero may persistently reduce the natural interest rate because in the economy, requiring post-crisis restructuring, they impede the process of restructuring and facilitate forbearance lending, which crowds viable economic agents out of credit through a number of channels. To reduce these risks, the central bank could voluntarily set a lower bound for interest rates cuts at, for instance, $2 \%$. The boundary appropriate for a given economy should be a function of its growth rate and interest rates in the pre-crisis period. We argue that irrespectively of the central bank's credibility such a change in the monetary policy conducting in economies requiring post-crisis restructuring would bring better outcomes than keeping interest rates close to zero.
\end{abstract}

Keywords: interest rates close to zero, new Keynesian analytical framework, restructuring, credit.

JEL classification: E51, E58, G34

\section{Introduction}

This article analyses a possible impact of keeping the interest rates close to zero on the natural interest rate after the bursting of the asset bubble that triggered the financial crisis in 2008. Thus, the focus lies on economies requiring post-crisis restructuring.

Section 2 identifies the adverse effects that could result from a persistent decrease in the natural interest rates. Section 3 explains why the interest rates close to zero may lead to such a decrease. Section 4 shows when it is likely to occur. Section 5 outlines some guidelines for the monetary policy after the bursting of the asset bubble. Section 6 provides conclusion of the analysis.

* Piotr Ciżkowicz, Warsaw School of Economics (pcizko@sgh.waw.pl ); Andrzej Rzońca, Monetary Policy Council in the National Bank of Poland, Warsaw School of Economics (andrzej.rzonca@nbp.pl). Authors would like to thank Leszek Balcerowicz, Andrew Filardo, Hervé Hannoun, Ronald McKinnon, Roger Myerson and two anonymous referees for their helpful comments on the early version of this paper. The usual caveats apply. 


\section{Potential Consequences of Interest Rates Close to Zero}

During the recent crisis all the major central banks lowered their interest rates to a level close to zero. Such a response to the crisis has been expected to reduce the risk of deflation which could limit the capacity of the monetary policy to influence aggregate demand and price dynamics. It has also been justified by weakening of the transmission mechanism (see e.g. IMF, 2010) In the standard New Keynesian (NK) analytical framework used by the central banks (e.g. Christiano, Trabandt and Walentin, 2011 or Walsh, 2009), these conditions may be illustrated, firstly, as an exogenous, transitory decrease in $r_{t}^{n}$, and secondly, as a change in $\sigma$ in the expected IS curve (Equation 1) or in $\beta$ or $\kappa$ in the NK Philips curve (Equation 2).

$$
\begin{gathered}
x_{t}=E_{t} x_{t+1}-\left(\frac{1}{\sigma}\right)\left(i_{t}-E_{t} \pi_{t+1}-r_{t}^{n}=-\left(\frac{1}{\sigma}\right) \sum_{k=0}^{\infty} E_{t}\left(i_{t+k}-E_{t} \pi_{t+k+1}-r_{t+k}^{n}\right)\right) \\
\pi_{t}-\pi^{T}=\beta E_{t}\left(\pi_{t+1}-\pi^{T}\right)+\kappa x_{t}+e_{t}
\end{gathered}
$$

where:

$x_{t}$ output gap;

$i_{t}$ interest rate;

$\pi_{t}$ inflation;

$\pi^{T}$ inflation target;

$r_{t}^{n}$ natural real interest rate;

$e_{t} \quad$ cost shock

However, actions of major central banks do not seem to have accounted for the fact that interest rates close to zero may consolidate a low level of $r_{t}^{n}$ after its decline caused by the crisis or postpone its return to the pre-crisis level, if the economy hit by the crisis requires restructuring. In the standard analytical framework changes in $r_{t}^{n}$ result (mainly) from exogenous disturbances - in growth in TFP, and in households' preferences.

where:

$$
r_{t}^{n}=\rho+\sigma E_{t}\left(g_{t+1}\right)+\sigma E_{t}\left(c_{t+1}\right)
$$

$\rho-\ln \beta$-rate of time preference

$\sigma$ relative risk aversion

$g_{t}$ growth in TFP

$c_{t}$ growth in consumption per unit of effective labour

Economic intuition behind the dependence of natural interest rates on TFP growth is the following. First, in the long run, the interest rate should be higher than the growth rate of per capita income. Otherwise, the incentive to save would be weak. One could take out a loan and finance the increased current expenses, and then take out another loan to pay off the interest and wait until the debt-to-income ratio drops to zero. In other words, larger spending today would not require lower expenditure in the future (see e.g. Fischer and Easterly, 1990). Second, the TFP growth is the fundamental source of economic growth and the only one which is potentially inexhaustible. 
Our estimates, based on Kalman filter, ${ }^{1}$ of $r_{t}^{n}$ for Japan indicate that its average level decreased from 2.1\% in the years 1980/Q1-1993/Q2 to 0.8\% in the following years, when interest rates have been close to zero. ${ }^{2}$ The decrease in $r_{t}^{n}$ after the asset bubble burst turned out to be highly persistent. This persistence cannot be explained by the financial crisis itself. It is worth noting that in Sweden, which in the beginning of the 1990s experienced a financial crisis of similar depth, ${ }^{3} r_{t}^{n}$ sharply decreased at its onset, but fairly quickly returned to the average level of $2 \%$. This development was accompanied by a reduction of policy rate from 10\% in 1990/Q1 to $4.5 \%$ in $1994 / \mathrm{Q} 1$ followed by an increase to $7.5 \%$ in $1995 / \mathrm{Q} 3$.

Figure 1

Natural Rate of Interest in Japan (1980-2011)

Source: Own calculations based on ReutersEcowin data

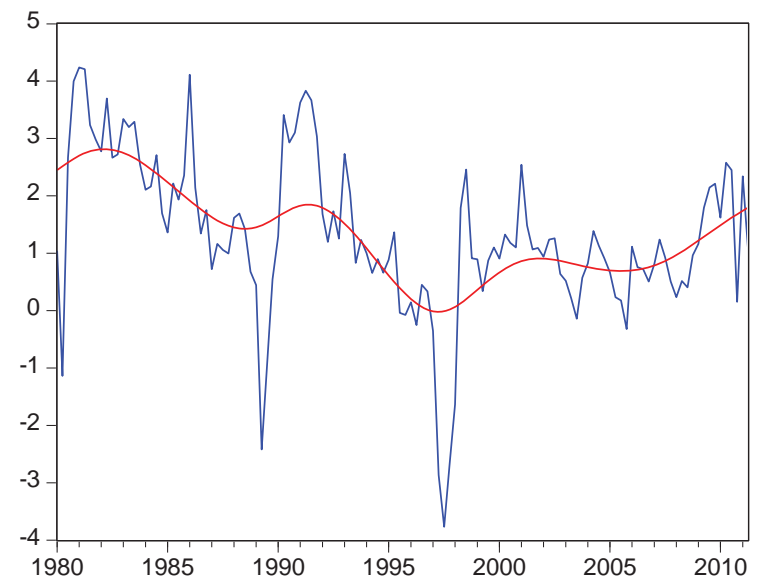

1 Kalman filter has been used to estimate $r_{t}^{n}$ for example by Laubach, Williams (2001) and BrzozaBrzezina (2006). This approach is based on estimation of two equations model of the form:

(1) $\Delta \pi_{\mathrm{t}}=\alpha_{1} \Delta \pi_{\mathrm{t}-1}+\alpha_{2}\left(i_{t-1}-E_{t-1} \pi_{t}-r_{t-1}^{n}\right)+\varepsilon_{1, t}$

(2) $r_{t}^{n}=\beta_{1}+\beta_{2} r_{t-1}^{n}+\varepsilon_{2, t}$

We used quarterly data covering the period 1980/Q1 - 2011/Q2 for Japan and, because of restricted availability of inflation expectations, 1987/Q2 - 2011/Q2 for Sweden. Detailed results are available upon request.

2 We consider interest rates lower than $2 \%$ as interest rates close to zero. $2 \%$ is a threshold below which they did not decrease until recently in the UK, for which time series reaching the seventeenth century is available (Bullard, 2010). Taking into account the data collected by Homer and Sylla (2005), such a threshold seems to be sensible also in the case of many other countries than the UK, but obviously it is purely conventional. In the following sections we discuss some factors due to which its actual value (i.e. the value responsible for the negative phenomena described in this article) may differ across countries.

3 In Sweden, in contrast to Japan, there was no substantial decrease in share prices, since they had not increased considerably prior to the crisis. But the scale of both the increase in property prices before the crisis, and their decline during the first two years after the crisis was much larger in Sweden than in Japan (although it should be noted that in Japan, this decrease was continued in the next several years, and was particularly strong in the case of commercial real estate, especially in major cities; see e.g. Hoshi and Kashyap, 2004.) Credit to the private sector to GDP ratio was growing faster before the crisis in Sweden than in Japan (although its level in Sweden remained lower than in Japan.) Finally, in Sweden, unlike in Japan, there was a currency crisis. Currency crises are usually associated with particularly high costs immediately after their occurrence (see, e.g. Cecchetti et al., 2009). 
Figure 2

\section{Natural Rate of Interest in Sweden (1987-2011)}

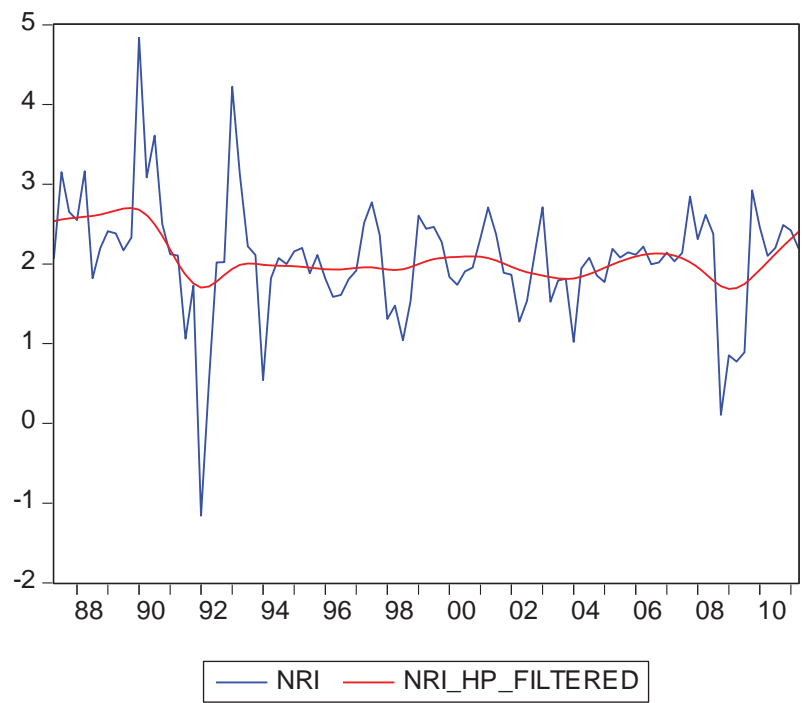

Source: Own calculations based on ReutersEcowin data

Interest rates close to zero would have 3 negative effects should they persistently decrease $r_{t}^{n}$.

- They would mean weaker growth. It is unlikely that they could reduce $r_{t}^{n}$ in any other way than by curbing $g_{t}$ (see Equation 3 and Section 3 )

- They would weaken the impact of interest rate reduction on $x_{t}$ and $\pi_{t}$ (see Equations 1 and 2). This weakening of the transmission mechanism is consistent with the empirical analysis of the consequences of the crises (e.g. the IMF, 2010), but, in this case, it would be the effect of aggressive cuts in $i_{t}$, generally considered an appropriate response to such weakening.

- They would limit the central bank's capacity to influence $x_{t}$ and $\pi_{t}$ in a longer term. The decline in $r_{t}^{n}$ would reduce the difference in price dynamics between two steady states, determined by the Fisher equation and the Taylor rule (e.g. Bullard, 2010). This difference is equal to the sum of $r_{t}^{n}$ and $\pi^{T}$. One may also show that a decline in $r_{t}^{n}$ would increase the inflation rate at which the central bank loses the ability to pursue an active policy understood as cutting the nominal interest rate to a scale larger than the expected decline in inflation (Figure 3.) 


\section{Figure 3}

\section{Interest Rates and Inflation}

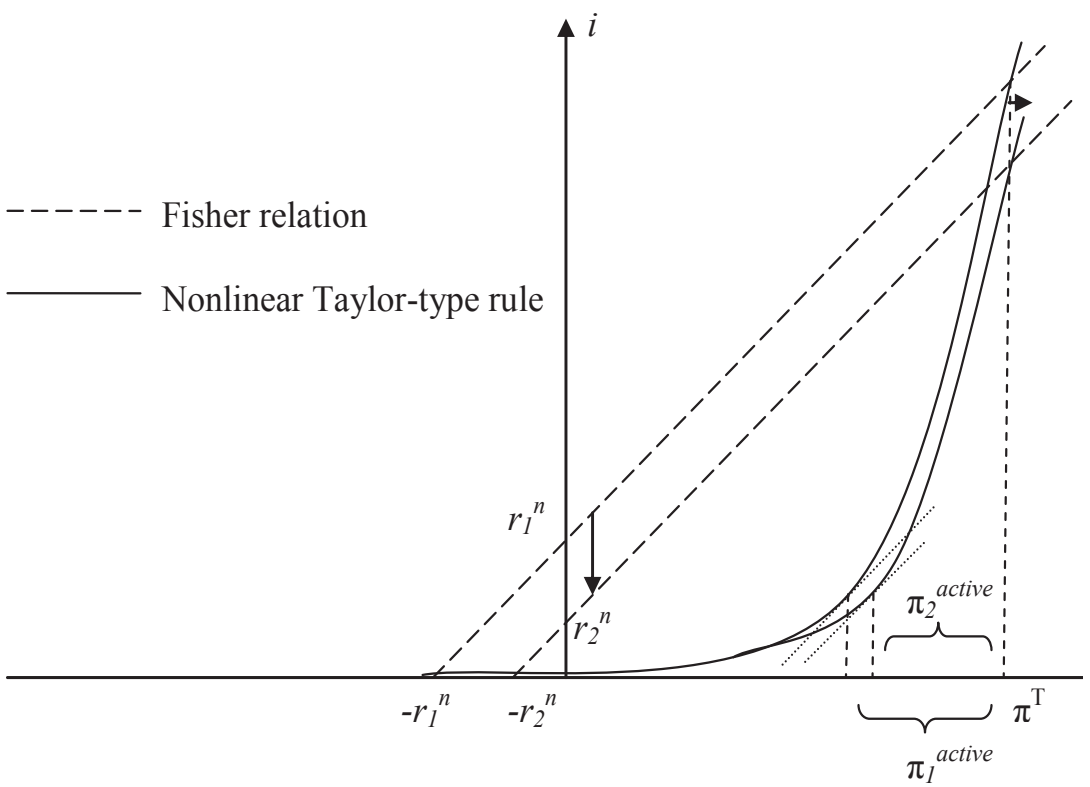

\section{Impact on Restructuring}

Interest rates close to zero may weaken $g_{t}$ and - as a result - reduce $r_{t}^{n}$ because they impede restructuring, i.e. the key process in a post-crisis economy. In particular, they lower exit rates, lock assets in their current uses, and weaken incentives to improve productivity in low-productivity businesses. We discuss these effects in a more detailed way below.

Despite the fact, that the bursting of the bubble resulted in the value of many assets decrease below the debt incurred for their purchase, these assets may not change hands provided they generate income in excess of debt service costs. Interest rates close to zero mean that even if a particular economic agent will never be capable of repaying borrowed principal, it is able to pay interest. That ability, on the one hand, increase difficulty, caused by the crisis, in assessing the financial stance of the debtors, and on the other hand, encourages banks to renew funding to their customers.

The ability of almost all economic agents to regularly pay off the interest reduces the risk that banks will race to withdraw from funding their borrowers. If the banks do not have to be concerned about the decisions of other creditors against other debtors, the difficulty in assessing financial stance of the debtors may not be a sufficient reason for banks to refuse a funding renewal. Banks have more time to identify, good and bad debtors, respectively. This time allows them to avoid unnecessary costs of seizure and sales of assets of good debtors (Barro, 1976). At the same time, however, the possibilities 
of this kind of identification do not expand. Therefore, the banks may not take advantage of that time and only delay the restructuring of their loan portfolio. The risk of delaying the restructuring by banks becomes more severe, the more profound is the belief that the central bank will keep interest rates close to zero as long as the problems in the banking sector will not be solved. That belief increases the relative value of the option to delay withdrawal from funding of excessively indebted economic agents. The value of that option is related to three factors: first, a possible improvement of the financial stance of the debtors; second, a potential increase in asset prices, which would increase the value of liquidation of debtors' assets; and third: the banks' chances to rebuild their capital needed to recoup losses (see e.g. Dixit and Pindyck, 1994, Chapter 7). At the same time, the cost of opportunities lost due to the delay in the restructuring of the loan portfolio decreases. Fast restructuring, when the other banks postpone it, does not significantly increase future profits, because the profits depend, much stronger than in more prosperous times, on the stance of the whole sector.

Reversal of strategic complementarity of banks' decision to uphold or to withdraw funding to their customers after the speculative bubble bursting can take place before the interest rates decrease close to zero. However, the lower the interest rates, the more likely the reversal.

In the case of the non-financial sectors, the results of loan 'evergreening' results in impeding flows of the production factors and dwindling informative value of asset prices. Some economists (Kobayashi, 2000) also point to the fact that forbearance lending increases uncertainty, which may incite enterprises to postpone the execution of new projects and discourage them from specializing.

To allow Ponzi finance borrowers to join the group of speculative finance (Minsky, 1986), their newly incurred loans should have shortest maturity possible. ${ }^{4}$ Shortening debt maturity enables interest payments to converge to zero. ${ }^{5}$ Yet, it also means lower stability of debt financing which undermines the debtors' incentives to undertake corrective measures. These incentives are weak anyway due to debtors' awareness of banks having an interest in rolling loans over, regardless of debtors' financial condition. Debtors facing financial problems cease to perceive the possibility of banks' withdrawing from financing as a real threat. They consider such a withdrawal as a function of variables beyond their control, such as, for example, banks' capital or interest rate level. As a result, contrary to what is suggested by the standard literature (e.g. Flannery, 1994), banks do not increase their control over debtors' behaviour by shortening the debt maturity.

4 Empirical evidence of shortening debt maturity due to low interest rates is scarce. Smith (2003) documents such a shortening in the case of Japan in response to problems with identifying viable borrowers.

5 Granting loans with variable interest rate without changing their maturity would have the same effect. Yet, given high uncertainty about borrowers' ability to repay loans at normal interest rate level, the chances of loan maturity not being shortened seem unlikely, unless banks introduce some other measures (e.g. tightened covenants) to have an option of quick withdrawal of funding. 
To prevent excessively indebted enterprises from taking actions which would increase the variance of payoffs from their projects and thereby have an adverse effect on the expected value of payoffs to creditors, banks have to convince them that detection of any sign of such actions will result in immediate funding withdrawal, regardless of circumstances. Such a threat will be effective only if excessively indebted enterprises consider the costs of such a withdrawal to be high. Those costs are increased by low interest payments and low chances of obtaining funding for any new project in the case of default (those chances in turn depend on the difficulty in assessing the quality of different projects). The weight of both those factors is a function of the expected length of the period in which they hold (i.e. when interest rates are possibly low, and the end of post-crisis restructuring in the economy possibly distant).

As banks do not observe those costs, they are likely to attach a great importance to regular interest payoffs and to the stability of debtors' financial stance. The resulting focus of excessively indebted enterprises on preventing the deterioration of their financial situation reduces their chances for a significant increase in productivity. Such a focus rules out innovations (which are the main source of productivity growth), since innovations always involve the risk of failure. At the same time, efforts made to maintain status quo reduce the chances of those enterprises to free themselves from the burden of excessive debt by an increase in their valuation. The main part of the company's value is not due to its assets, but due to its growth prospects (e.g. Myers, 1977 and Pindyck, 1988).

In the case of Japan, where interest rates have been close to zero since $1993^{6}$ there is a multitude of evidence to support deterioration in distortions on factor markets (e.g. Nakakuki et al., 2004), forbearance lending (e.g. Peek, Rosengren, 2005 or Kobayashi et al., 2002), decline in the informative effectiveness of the asset markets (e.g. Hamao et al., 2007), and shortening of loan maturities (e.g. Smith, 2003). Yet, if these phenomena have ever been associated with zero interest rates, this has been limited to isolated hints.

It is worth remarking once again, that for restructuring to be impeded, interest rates do not need to decrease close to zero, although interest rates close to zero have obviously the strongest negative impact on restructuring. It is enough that they return to levels that sparked the crisis by enabling agents incapable of regular-term loan repayment to take out loans. As the interest rates which triggered the crisis may differ across countries, this level should also be different. It should be higher in countries reporting a rapid growth in the pre-crisis period and lower in countries reporting a weak growth (see Equation 3).

6 Formally, Bank of Japan introduced a policy of zero interest rates on February 12, 1999. However, in practice, according to the definition adopted in this article, interest rates were kept close to zero since September 21, 1993. Bank of Japan reduced then the discount rate below 2\% (to 1.75\%), earlier, i.e. on February 4, 1993, equating it with the pre-crisis minimum $(2.5 \%)$. Since the summer of 1995 it has been kept below $0.5 \%$. 


\section{Impact on Credit (and on other sources of external financing)}

Impeded restructuring does not necessarily have to decrease $g_{t}$ and $r_{t}^{n}$, provided two conditions are met:

- First, the entry rate and productivity growth in viable enterprises depend on loan availability, and

- Second, interest rates close to zero are capable of increasing the flow of new credit to viable economic agents during the crisis.

The first of these conditions appears to be met. There is a very extensive literature (surveyed e.g. by Levine, 2005) on the positive impact of financial intermediation on economic growth. There are also studies that directly indicate the positive effect of the availability of external financing on the entry rate and on the dependence of market shares of enterprises on their productivity (e.g. Black, Strahan, 2002 and Kerr, Nanda, 2009). In this section, we focus on the second condition.

In the simplest NK analytical framework there is no role for credit. However, during the recent crisis, central banks have intensified their efforts to assign credit an important function in their analytical framework. Credit has gained this function due to various financial frictions (financial accelerator, collateral constraints, capital requirements) introduced into the NK analytical framework. The introduction of these frictions has modified the expected IS curve, which may have the following form (e.g. Christiano, Trabandt, Walentin, 2011 or Walsh, 2009)

$$
x_{t}=E_{t} x_{t+1}-\left(\frac{1}{\sigma}\right)\left(i_{t}-E_{t} \pi_{t+1}-r_{t}^{n}\right)-\gamma_{1} i_{t}-\gamma_{2} \psi_{t}
$$

where:

$\psi_{t}$ - measure of financial frictions.

Such a modification may serve (see Equation 4) and indeed, has served (e.g. BIS, 2010) as an additional argument in favour of maintaining interest rates close to zero during the crisis. Yet, it does not account for the fact that interest rates close to zero may lead to forbearance lending in economies that require post-crisis restructuring. Forbearance lending may in turn enhance financial frictions and, as a result, curb the credit flow reaching viable economic agents via at least seven mechanisms.

- First, banks may create the image of agents applying for a loan on the basis of a non-restructured loan portfolio.

- Second, the fact that a particular agent has recourse to borrowing may cease to bring a "relationship" benefit (see e.g. Kashyap, Stein, Wilcox, 1993, or Oliner, Rudebush, 1995); on the contrary, it may signal financial problems. As a result deleveraging may become a way of manifesting financial strength. It gives viable enterprises the guarantee to differentiate themselves from bad debtors as bad debtors are hardly able to reduce their debt. 
- Third, the more serious the problem of undisclosed NPLs, the larger (and the more expensive) the scope of information which should be examined by banks prior to granting a loan. For example, credit history loses its information value, because even bad borrowers may have positive credit track records. Moreover, banks may have to monitor not only potential borrowers but also their partners, and partners of their partners, etc. (Caballero, Simsek, 2009). At the same time, the absence of a considerable risk of competitors taking over financing of a profitable project and the possibility of earning on liabilities thanks to various charges enable banks to postpone costly state verification.

- Fourth, banks uncertain of the current value of their loan portfolios may not be able to determine the scale of lending growth that does not pose a risk of capital requirements' breach.

- Fifth, enterprises which take advantage of forbearance lending may, by underpricing their products and putting an upward pressure on wages, reduce the profitability of other companies (Caballero et al., 2006). Lower profits, in turn, diminish enterprises' ability to repay loans and their propensity to take out loans.

- Sixth, an unrestructured loan portfolio may be an obstacle for banks to gain access to new capital, without which no increase in lending is possible. These difficulties may also affect sound banks as issuing new shares might be perceived as a sign that the banks hare not restructured its loan portfolio. Lack of access to new capital enhances incentives to 'evergreen' loans, as 'evergreening' facilitates meeting to meet capital requirements.

- Seventh, delays in loan restructuring may urge banks to increase their liquid reserves and to purchase 'safe' assets: treasury bonds, foreign assets and commodities. ${ }^{7}$ Another stimulus inducing banks to build up liquid reserves and purchase bonds is connected with banks' limited access to new capital and the method of calculating capital adequacy ratio. The reason for increasing liquid reserves is also zero profits on sharing liquidity (cf., e.g. McKinnon, 2011) and the possibility to earn on liabilities.

All of the above mechanism except for the fifth one, have adverse effect in credit supply. The second and the fifth mechanisms reduce the credit demand.

The second, the third, the fifth and the seventh mechanisms may also limit the use of other sources of external financing than credit in economies requiring post-crisis restructuring.

- Amidst the difficulties in the assessment of their financial situation, enterprises may be stigmatized for applying for any external funding.

- Not only banks, but also investors are forced to examine an extended set of information before making a decision on financing a particular project if a major risk that its completion might be threatened by the changing environment exists.

7 Commodities, in a given commodity market, have uniform characteristics and are consumed during the production process, which makes their resale a certain option, and, in the case of most countries, have prices which do not depend on their economic situation. 
- A decline in the corporate sector's profitability resulting from propping up bankrupt companies limits the sector's ability to repay loans and its propensity not only to take out loans but to also incur any liabilities.

- Delays in loan restructuring may incite not only banks but also other investors, including foreign entities, to purchase safe assets.

All four channels may particularly strongly affect equity finance (cf., e.g. Myers, Majluf, 1984).

The precondition for all seven mechanisms to function is forbearance lending. Interest rates close to zero, for the reasons stated in the previous section, makes this kind of lending much easier and significantly strengthens incentives for it.

There is ample evidence of crowding viable enterprises out of credit in Japan after the bursting of the asset bubble (see, e.g. Ahearne, Shinada, 2004; Caballero et al., 2006; Hosono, Sakuragawa, 2003). Moreover, these enterprises have not substituted bonds for credit. The share of bonds in total debt has decreased not only among Japanese enterprises with low return on assets but also in enterprises with (a) high ROA (e.g. Peek, Rosengren, 2005.) Lastly, the access to equity finance has also considerably narrowed (e.g. Hamao et al., 2007).

These studies do not decide the question of economic importance of the seven mechanisms described above through which interest rates close to zero may have a negative impact on the use of credit and other types of external financing. It is quite likely that due to the crisis, viable firms in Japan would have been crowded out of external financing also in the case where interest rates had stayed clearly above zero. Interest rates close to zero exacerbated that crowding out the effect to the extent to which they increased forbearance lending.

The reasoning presented in this section suggests the following picture of the impact of interest rates close to zero on the credit growth. Immediately after the outbreak of the crisis, such a level of interest rates inhibits credit decline. But this is mainly caused by a delay in the write-offs of bad loans and in balance sheet repairs in the enterprises with affected by the crisis. The delay limits the flow of credit to enterprises with healthy balance sheets and could use the credit for profitable projects. However, write-offs of bad loans and balance sheet repairs cannot be postponed infinitively. Thus, interest rates close to zero do not prevent a credit decrease to the GDP ratio, but only protract this process. The side effects of that protraction can increase the scale of the decrease.

The outlined credit momentum under the influence of interest rates close to zero exacerbates their negative effects on the restructuring described in the previous section. Firstly, the credit is directed to existing borrowers and therefore does not increase the entry rate. Secondly, it is used to sustain activities already carried out instead of financing new projects that could increase the incumbents' productivity. Thirdly, it goes to the excessively indebted entities, while the other enterprises, especially the most profitable, are likely to deleverage, treating the deleveraging as a way to manifest their financial credibility. Thus, the credit ceases to be conducive to increases in market shares of the most productive enterprises. 


\section{Some Guidelines for the Monetary Policy after the Bursting of the Asset Bubble}

There exist numerous studies (e.g. Eggertsson, Woodford, 2003) showing that zero lower bounds should not deprive central banks of the capacity to stabilize the economy provided that the banks can credibly commit to keeping $i_{t+j}$ at a low level for a sufficiently long period. According to the NK framework, expectations that the central bank will tolerate an aggregate demand growing in excess of the potential output in some future period should increase the aggregate demand in the current period. Those expectations should also contribute to an increase in inflation expectations, which would lower the real interest rate, further stimulating aggregate demand (Equations 1 and 2). ${ }^{8}$

According to the available literature, to increase the credibility of the central bank's commitment to keep the real interest rates below $r_{t}^{n}$ (once it is possible) is to supplement that commitment by quantitative easing. The larger the balance sheet of the central bank, the greater its losses if it did not keep its commitment with regards to the path of interest rates (e.g. Bernanke, Reinhart and Sack, 2004 or Clouse et al., 2003). ${ }^{9}$

However, using the same logic, one may claim that keeping interest rates low but clearly above zero (at, say, $2 \%$ ) should not deprive central banks of the capacity to stabilize the economy. At the same time, both central banks' practice and economic theory suggest that quantitative easing could (and even should) ${ }^{10}$ be started before the interest rates are reduced close to zero. Yet, such a policy should not entail as large a risk of consolidating the low level of $r_{t}^{n}$ or of postponing its return to the pre-crisis level as the policy of keeping interest rates close to zero in an economy requiring post-crisis restructuring. ${ }^{11}$

A reduction of that risk could enable the central bank to establish a less distant horizon of the return to the pre-crisis rule in the monetary policy than otherwise, which would increase the chances that its commitment is considered credible. The less distant the

8 Some economists (e.g. Svensson, 2004) treat the management of inflation expectations as an additional instrument in monetary policy. Others (e.g. Eggertsson, Woodford, 2003) consider shaping the expectations with regard to the interest rate to be essentially the only instrument of the central bank.

9 These losses, however, would arise only in the case of sales by the central bank of securities purchased under quantitative easing programs, prior to their maturity. In addition, it follows from the estimates of losses, carried out for the United States that they could hardly be large. That casts doubt on effectiveness of quantitative easing in increasing the credibility of the central bank's commitment to keep real interest rates below $r_{t}^{n}$ in some future period (Cecioni, Ferrero, Secchi, 2011). However, at least some empirical research on the effects of quantitative easing suggests that it lowers long-term interest rates mainly by lowering the interest rate path expected by economic agents (although those studies do not indicate mechanisms, through which it lowers that path; see, e.g. Woodford, 2012.)

10 Bernanke and Reinhart (2004) claim that the start of the quantitative easing before lowering interest rates close to zero may reduce the risk of the impression (erroneous in their opinion) that the central bank has used all available means. That impression may occur when interest rates approach zero.

11 It is worth remarking that with the interest rates close to zero there is a serious risk that quantitative easing will mainly support weaker banks (e.g. Baba et al., 2005; Kobayashi, Spiegel, Yamori, 2006 or Spiegel, 2006). With interest rates clearly above zero its impact on the pace of restructuring may be opposite. The resulting increased liquidity should facilitate ownership changes forced by the interest rates. 
horizon of the return to the pre-crisis rule, the easier the persuasion of economic agents that the central bank will accept an economic boom, once the economy recovers from the crisis (Equations 1 and 2), as well as that the exceptionally low level of interest rates is truly exceptional. ${ }^{12}$

The established horizon of the return to the pre-crisis rule would be less distant in the case of keeping the interest rates at, for instance, $2 \%$ than at a level close to zero, if interest rates close to zero had sufficiently strong or persistent negative impact on $r_{t}^{n}$ (Equation 1). Our estimates of $r_{t}^{n}$ for Japan (Section 2) as well as the comparison of the average length of period preceding the return of growth after the financial crisis to its pre-crisis rate (3 years; see IMF, 2009) with the length of that period for Japan (no return so far) suggests that this negative impact may be both strong and persistent in an economy requiring post-crisis restructuring.

Surprisingly little empirical research has been devoted to the effects of crises on the perception of central banks. From existing studies (Gros, Roth, 2010) one may conclude that crises have a strong negative impact on the credibility of central banks. If economic agents believe that the central bank is responsible for the crisis, they may come to the conclusion that its actions will lead to another crisis and the slump of aggregate demand. The impact of interest rate cuts on the aggregate demand will then be weakened or neutralized by the downward revision of aggregate demand expectations. In such an environment, the central bank's decision to keep interest rates low but clearly above zero (at, say, 2\%) would also be less risky than to keep them close to zero. In both cases interest rates cuts may fail to stimulate the aggregate demand, but the former policy would bear a more limited risk of impeding restructuring than the latter.

Since interest rates impeding restructuring may differ across countries (Section 3), there is no unique level at which the central bank should set a voluntary bound for interest rates cuts. This bound should be a function of economic growth and interest rates in the pre-crisis period.

The lower bound clearly above zero should be applied also in other economies, but for different reasons discussed elsewhere (Giavazzi, Giovannini, 2010; Hoenig, 2010 or Taylor, 2009). In their case, the central bank should avoid extremely low interest rates so as not to inflate the asset bubble, whose bursting could trigger a financial crisis.

\section{Conclusions}

During the recent crisis all the major central banks lowered their interest rates close to zero. Such a policy action has been fully justified by the NK analytical framework. However, at its current stage of development, the NK analytical framework abstracts

12 Schmitt-Grohe and Uribe (2010) show that this latter meaning of the credible commitment with regard to future policy is crucial for central bank's ability to influence price dynamics, and McKinnon (2011) explains why it is important for speeding up the closing of negative output gap. 
from the possible impact of interest rates close to zero on the natural interest rate after the bursting of the asset bubble which triggered the financial crisis.

Monetary policy failing to account for its impact on inflation expectations led to stagflation in the 70s. The omission of the monetary policy impact on the natural interest rate in economies requiring post-crisis restructuring may bring no less harmful consequences: a decrease in TFP growth and more limits in the central bank's capacity to influence the aggregate demand and price dynamics.

Interest rates close to zero may persistently reduce the natural interest rate in economies requiring post-crisis restructuring because they impede this process. Namely, they decrease the exit rate, hamper the flow of production factors between enterprises and weaken the incentives to improve productivity in low-productivity businesses. The impeded restructuring would not result in the natural interest rate decrease if its negative impact on TFP growth was offset (or outweighed) by the positive effects of the credit flow reaching viable enterprises. Yet forbearance lending facilitated by the interest rate close to zero may actually crowd viable economic agents out of credit through a number of channels.

To reduce these risks, the central bank in an economy requiring post-crisis restructuring could voluntarily set the lower bound for interest rates cuts at, say, $2 \%$. The actual bound should be set at a level related to growth and interest rates in the pre-crisis period. Irrespective of the central bank's credibility, such a change in the monetary policy conducting should bring better outcomes than keeping the interest rates close to zero.

\section{References:}

Aghion, P., Durlauf, S. N., eds. (2005), Handbook of Economic Growth. Volume 1A. Amsterdam, London, San Diego: Elsevier B.V.

Ahearne, A. G., Shinada, N. (2004), "Zombie Firms and Economic Stagnation in Japan". Paper presented at the conference Macro/Financial Issues and International Economic Relations: Policy Options for Japan and the United States at University of Michigan, Ann Arbor.

Baba, N., Nishioka, S., Oda, N., Shirakawa, M., Ueda, K., Ugai, H. (2005), “Japan's Deflation, Problems in the Financial System and Monetary Policy.” BIS Working Paper No. 188.

Barro, R. J. (1976), "The Loan Market, Collateral, and Rate of Interest." Journal of Money, Credit and Banking, Vol. 8, No. 4, pp. 839-856.

Bernanke, B. S., Reinhart, V. R. (2004), "Conducting Monetary Policy at Very Low Short-term Interest Rates." American Economic Review. Vol. 94, No. 2, pp. 85-90.

Bernanke, B. S., Reinhart, V. R., Sack, B. P. (2004), "Monetary Policy Alternatives at the Zero Bound: An Empirical Assessment." Brookings Papers on Economic Activity, Vol. 2, pp. 1-78.

BIS (2010), 80th Annual Report. 1 April 2009 - 31 March 2010. Bank for International Settlements, June.

Black, S. E., Strahan, P. E. (2002), "Entrepreneurship and Bank Credit Availability." Journal of Finance, Vol. 57, No. 6, pp. 2807-2833.

Brzoza-Brzezina, M. (2006), "The Information Content of the Natural Rate of Interest." Economics of Transition, Vol. 14, No. 2, pp. 391-412. 
Bullard, J. (2010), "Seven Faces of "The Peril." Federal Reserve Bank of St. Louis Review, Vol. 92, No. 5, pp. 339-352.

Caballero, R. J., Simsek, A. (2009), "Complexity and Financial Panics.” NBER Working Paper No. 14997.

Caballero, R., Hoshi, T., Kashyap, A. K. (2006), "Zombie Lending and Depressed Restructuring in Japan." NBER Working Paper No. 12129.

Cecchetti, S., Kohler, M., Upper, C. (2009), "Financial Crises and Economic Activity." Paper prepared for Federal Reserve Bank of Kansas City Symposium Jackson Hole.

Cecioni, M., Ferrero, G., Secchi, A. (2011), "Unconventional Monetary Policy in Theory and Practice." Banca D'Italia Questioni di Economia e Finanza (Occasional Papers) No. 102.

Christiano, L. J., Trabandt, M., Walentin, K. (2011), "DSGE Models for Monetary Policy Analysis," in Friedman. B. M., Woodford, M., eds., Monetary Economics, Volume 3A. Amsterdam, London, San Diego: Elsevier B.V.

Clarida, R., Gali, J., Gertler, M. (1999), "The Science of Monetary Policy: A New Keynesian Perspective." NBER Working Paper No. 7147.

Clouse, J., Henderson, D., Orphanides, A., Small, D., Tinsley, P. (2003), "Monetary Policy when the Nominal Short-Term Interest Rate is Zero." B.E. Journal of Macroeconomics, Vol. 3, No. 1.

Dixit, A. K., Pindyck, R. S. (1994), Investment under Uncertainty. Princeton: Princeton University Press.

Eggertsson, G. B., Woodford, M. (2003), "The Zero Bound in Interest Rates and Optimal Monetary Policy." Brookings Papers on Economic Activity, No. 1, pp. 139-233.

Fischer, S., Easterly, W. (1990), "The Economics of the Government Budget Constraint." World Bank Research Observer, Vol. 5, No. 2, pp. 127-142.

Flannery, M. J. (1994), "Debt Maturity and the Deadweight Cost of Leverage: Optimally Financing Banking Firms." American Economic Review, No. 84, No. 1, pp. 320-331.

Giavazzi, F., Giovannini, A. (2010), "Central Banks and the Financial System.” NBER Working Paper No. 16228.

Gros, D., Roth, F. (2010), "The Financial Crisis and Citizen Trust in the European Central Bank." CEPS Working Document No. 334.

Hamao, Y., Mei, J., Xu, Y. (2007), “Unique Symptoms of Japanese Stagnation: An Equity Market Perspective." Journal of Money, Credit and Banking, Vol. 39, No. 4, pp. 901-923.

Hoenig, T. M. (2010), "The High Cost of Exceptionally Low Rates." Lecture at the Bartlesville Federal Reserve Forum Oklahoma.

Homer, S., Sylla, R. E. (2005), History of Interest Rates. Hoboken, N.J.: Wiley.

Hoshi, T., Kashyap, A. K. (2004), "Japan's Financial Crisis and Economic Stagnation." Journal of Economic Perspectives, Vol. 18, No. 1, pp. 3-26.

Hosono, K., Sakuragawa, M. (2003), "Soft Budget Problems in the Japanese Credit Market." Nagoya City University Discussion Papers in Economics No. 345.

IMF (2009), What's the Damage? Medium-Term Output Dynamics after Financial Crises, in IMF, World Economic Outlook. Sustaining the Recovery. Washington DC: IMF.

IMF (2010), Central Banking Lessons from the Crisis. Washington, DC: IMF.

Kashyap, A. K., Stein, J. C., Wilcox, D. W. (1993), "Monetary Policy and Credit Conditions: Evidence from the Composition of External Finance." American Economic Review, Vol. 83, No. 1, pp. 78-98.

Kerr, W., Nanda, R. (2009), "Democratizing Entry: Banking Deregulations, Financing Constraints, and Entrepreneurship." Journal of Financial Economics, Vol. 94, No. 1, pp. 124-149.

Kobayashi, K. (2000), "Debt Overhang as a Delayed Penalty." MITI/RI Discussion Paper No. DOF35.

Kobayashi, K., Saita, Y., Sekine, T. (2002), "Forbearance Lending: A Case for Japanese Firms." Monetary and Economic Studies, Vol. 21, No. 2, pp. 69-92. 
Kobayashi, T., Spiegel, M. M., Yamori, N. (2006), "Quantitative Easing and Japanese Bank Equity Values." Journal of the Japanese and International Economies, Vol. 20, No. 4, pp. 699-721.

Laubach, T., Williams, J. C. (2001), "Measuring the Natural Rate of Interest." Federal Reserve Board Finance and Economics Discussion Series 2001-56.

Levine, R. (2005), "Finance and Growth: Theory and Evidence." in Aghion, P., Durlauf, S. N., Handbook of Economic Growth. Philadelphia: Elsevier, pp. 865-934.

McKinnon, R. I. (2011), "Beggar-Thy-Neighbor Interest Rate Policies." Journal of Policy Modeling, Vol. 33, No. 5, pp. 759-775.

Minsky, H. P. (1986), Stabilizing an Unstable Economy. New Haven, London: Yale University Press.

Myers, S., Majluf, N. S. (1984), "Corporate Financing and Investment Decisions when Firms Have Information that Investors Do Not Have." Journal of Financial Economics, Vol. 13, No. 2, pp. 187-221.

Myers, S. C. (1977), "Determinants of Corporate Borrowing." Journal of Financial Economics, Vol. 5, No. 2, pp. 147-175.

Nakakuki, M., Otani, A., Shiratsuka, S. (2004), "Distortions in Factor Markets and Structural Adjustments in the Economy." Monetary and Economic Studies, Vol. 22, No. 2, pp. 71-100.

Oliner, S. D., Rudebusch, G. (1995), "Is there a Bank Credit Channel for Monetary Policy?" FRBSF Economic Review, pp. 3-20.

Peek, J., Rosengren, E. (2005), "Unnatural Selection: Perverse Incentives and the Misallocation of Credit in Japan." American Economic Review, Vol. 95, No. 4, pp. 1144-1166.

Pindyck, R. S. (1988), "Irreversible Investment, Capacity Choice, and the Value of the Firm." American Economic Review, Vol. 78, No. 5, pp. 969-985.

Schmitt-Grohe, S., Uribe, M. (2010), "Liquidity Traps: An Interest-Rate-Based Exit Strategy." NBER Working Paper No. 16514.

Smith, D. C. (2003), "Loans to Japanese Borrowers." Journal of Japanese and International Economies, Vol. 17, No. 3, pp. 283-304.

Spiegel, M. M. (2006), "Did Quantitative Easing by the Bank of Japan "Work?'” FRBSF Economic Letter, No. 2006-28.

Svensson, L. E. O. (2004), "Comments on Bernanke, Reinhart, and Sack." Brookings Papers on Economic Activity, No. 2, pp. 84-93.

Taylor, J. (2009), Getting Off Track: How Government Actions and Interventions Caused, Prolonged, and Worsened the Financial Crisis. Stanford: Hoover Press.

Walsh, C. E. (2003), Monetary Theory and Policy. Cambridge and London: The MIT Press.

Walsh, C. E. (2009), "Using Monetary Policy to Stabilize Economic Activity." Paper prepared for the Symposium on Financial Stability and Macroeconomic Policy Jackson Hole.

Woodford, M. (2003), Interest and Prices. Princeton: Princeton University Press.

Woodford, M. (2012), "Methods of Policy Accommodation at the Interest-Rate Lower Bound." Paper presented at the Symposium the Changing Policy Landscape Jackson Hole. 